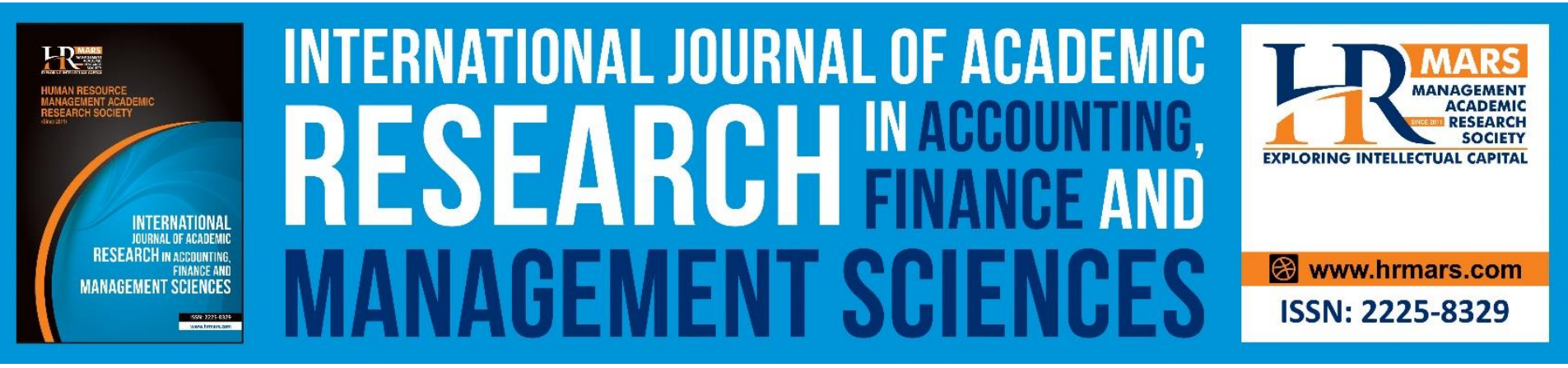

\title{
Utilization of Integrated Health Information Systems in Handling Serious Diseases Condition in Indonesia: A Literature Review
}

\author{
Andhika Dwitama Putra
}

To Link this Article: http://dx.doi.org/10.6007/IJARAFMS/v11-i2/9881

DOI:10.6007/IJARAFMS /v11-i2/9881

Received: 10 March 2021, Revised: 09 April 2021, Accepted: 04 May 2021

Published Online: 26 May 2021

In-Text Citation: (Putra, 2021)

To Cite this Article: Putra, A. D. (2021). Utilization of Integrated Health Information Systems in Handling Serious Diseases Condition in Indonesia: A Literature Review. International Journal of Academic Research in Accounting Finance and Management Sciences, 11(2), 1-12.

Copyright: (C) 2021 The Author(s)

Published by Human Resource Management Academic Research Society (www.hrmars.com)

This article is published under the Creative Commons Attribution (CC BY 4.0) license. Anyone may reproduce, distribute, translate and create derivative works of this article (for both commercial and non-commercial purposes), subject to full attribution to the original publication and authors. The full terms of this license may be seen

at: http://creativecommons.org/licences/by/4.0/legalcode

Vol. 11, No. 2, 2021, Pg. 1 - 12

http://hrmars.com/index.php/pages/detail/IJARAFMS

JOURNAL HOMEPAGE

Full Terms \& Conditions of access and use can be found at http://hrmars.com/index.php/pages/detail/publication-ethics 


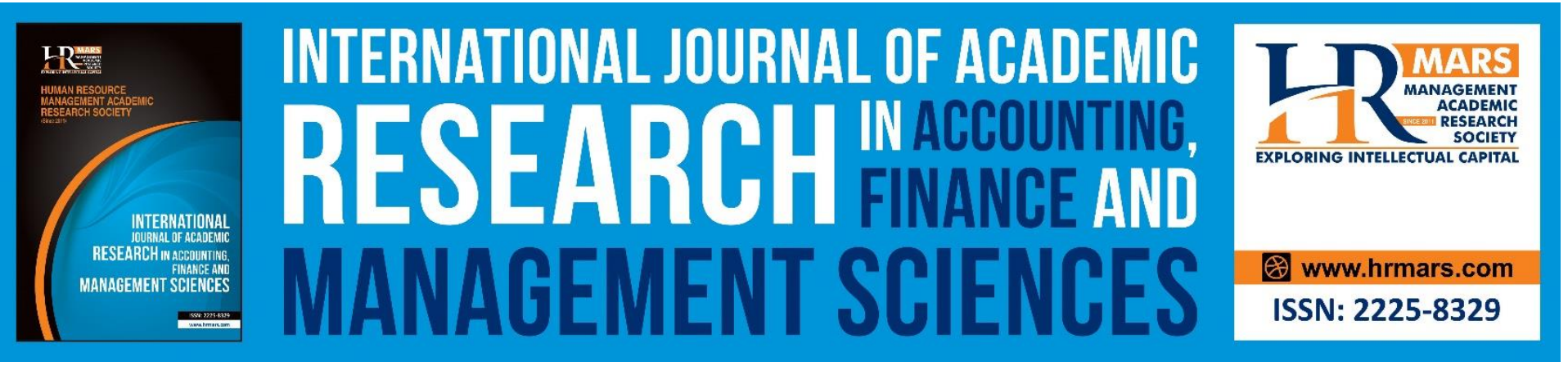

\title{
Utilization of Integrated Health Information Systems in Handling Serious Diseases Condition in Indonesia: A Literature Review
}

\author{
Andhika Dwitama Putra \\ Information Technology Entrepreneurship, Universiti Teknologi Malaysia \\ Email: andhikadwitamaputra@gmail.com
}

\begin{abstract}
With the coronavirus outbreak that happens worldwide, it can't be denied that every country has its problem when it comes to handle and control the Covid-19 situation, included Indonesia. Indonesia is one of the Southeast Asia countries infected by the virus lately, but the increasing number of infected patients also becomes the highest. The lack of information about the prevention and handling becomes the issues that occurred because of the geographic condition, it even makes the government harder to maintain and control the increasing number of infected patients. It also occurs because there is some lack of distribution of data from one hospital in the remote area to the data center. This research aims to figure out what the government of Indonesia must do to reduce, handle and cure the infection to the patient by expediting the flow of medical records between medic stakeholders, such as hospitals and Indonesia health institution, by using the Integrated Health Management Information System and Information Technology to improve the quality of the medical procedure as well as guarantee the improvement of the patient's quality lives. Furthermore, the government must spread valid, checked, and update information regarding the condition and the situation faced by the public, so the public can well-informed and keep maintain their health condition.
\end{abstract}

Keywords: Covid-19, Health Management Information System, Information Technology.

\section{Background}

With the growing use of technology these days, especially in this technology 4.0 era, people can access, look into, and find the information regarding any information in real-time on all over the world. One of the information that can be gained is information about the occurring pandemic situation because of the Covid-19 virus. The COVID-19 virus which on the beginning was detected and known from China at the end of December 2019, now has been infecting more than 7 million people all over the world and killed approximately more than 400,000 people (WHO). Covid-19 is caused by 2019-nCoV infection. nCoV has similar characteristics with other viruses like SARS-CoV and MERSCov. It is believed that the 2019-nCoV was zoonotic (means it is spread by the animals, in this case, a 
INTERNATIONAL JOURNAL OF ACADEMIC RESEARCH IN ACCOUNTING, FINANCE AND MANAGEMENT SCIENCES

Vol. 11, No. 2, 2021, E-ISSN: 2225-8329 ๔ 2021 HRMARS

bat). But, the host of this virus is still not clear. Even though the sub tropic countries mostly are getting infected like Europe and America, it can be denied that even in a tropical country like Asia also can be infected. When countries like Malaysia, Thailand, and Singapore become the first country in South East Asia that reported their citizen are getting infected by this virus by late January, Indonesia on the other hand, confirmed its first positive case on the first of March (Loasana, 2020).

Unprepared medical matters, the denial act from the government, and poor early response about the virus become a real disaster after the Indonesian government confirmed that there were 2 citizens were getting infected by foreign nationals (Beritasatu, 2020; Sheany, 2020). The government immediately made some scenarios to prevent the spread by minimalizing massive activities like mass transportation, mass worship, a public school as well as shopping malls just by when other countries like Malaysia, had announced to lock down the country at the same time. With more than 17,000 islands and 250 Million citizens in Indonesia, making it hard for the government to control and handle the virus with this geography condition (ASEAN, 2018). The biggest island in Indonesia, Java island, becomes the first area as the center of this virus spread which at the end of March, the virus has been spreading all over big islands and provinces in Indonesia, even in the remote and rural areas (Syakriah, 2020). This disaster occurred since there is a lack of the integrated health information system that been used to give information regarding COVID-19. People of Indonesia confuse which information that spread in social media as well as on the internet to be used to prevent, handle, as well as how to cure the disease since some invalid data can be found on the internet, and there is some mistaken information (Eloksari, 2020). Because of the increasing number of positive cases, the Indonesian government then instructs to do the large scale social restriction on several provinces and areas that impacted the most by the virus on the first of April (Indonesia 2020).

In Indonesia, people who have a high chance to get infected or getting interacted by the positive patient can be categorized PDP (pasien dalam pengawasan / supervised patient), ODP (orang dalam pantauan / monitored patient) and OTG (orang tanpa gejala / person without symptom). These classifications however make people more confused, since many diseases that occur in Indonesia, also have similar symptoms like COVID-19 (Force, 2020). Dengue is a yearly endemic disease that infected people in Indonesia that has a similar symptom with the COVID-19 symptom. Moreover, in the Jambi area in Sumatra province, several people also infected by the dengue in the pandemic situation. It makes it hard for the medical staff to configure and determine whether the patients were infected by the COVID-19 or the dengue (Suprapto, 2020). With these classifications, many people who believe that they have one of the similar symptoms, inspect the public and private hospitals. In the panic situation, with the increasing number of positive cases and lack of medical equipment in almost all over the hospitals in Indonesia, many hospitals decided to limit the patient who comes with a mild symptom like mild cough and flu. The government also suggests to people who have a mild symptom to do the self-quarantine for 14 days to prevent the spread between the positive patient and the high-chance people with a mild symptom (Antara, 2020). People who have been categorized as OTG have a higher chance to infect the virus undetected since they don't have any symptom but they carry the virus inside their bodies (Muthiariny, 2020).

Besides the invalid and unclear data regarding COVID-19, there is also a problem identified when the Indonesia government under the COVID-19 task force clarified that they do the wrong input about the data of the patient (Saubani, 2020). This can happen since there is a complicated bureaucracy since there are a lot of health institutions from the public to private and the geographical condition in Indonesia that makes it hard to ensure the integrity of the data. It is resulting in some error in 
INTERNATIONAL JOURNAL OF ACADEMIC RESEARCH IN ACCOUNTING, FINANCE AND MANAGEMENT SCIENCES

Vol. 11, No. 2, 2021, E-ISSN: 2225-8329 ๔ 2021 HRMARS

positive patient mapping, until the error number of the total number of infected patient and death patient. Because of this, many NGOs in Indonesia protested to the government about the data transparency so people can know the truth and there is no information that hidden. They also make some surveys or questioners about how good the Indonesia government to solute this pandemic situation (Loasana, 2020). This data can be used to determine what should the government do to minimalize the error as well as the death rate that occurs by the virus. Also assume how many people that targeted to be vaccinated later, and how badly this pandemic can affect the economy on a big scale in Indonesia. The use of big data and integrated information system seem can be the perfect solution not only in Indonesia but also in another country to get the best effort to end the pandemic with small death rate yet still keep the economic still running and maintain the national governance.

Based on the background for this journal, I point some hypothesis that might be used to solve the problems, which are:

1. Can the Health Management Information System give an accurate as well as guarantee the truthiness of the data in this pandemic situation in Indonesia to be shared with the citizen?

2. What can the Indonesia government do to the data (from medical records to the data survey regarding the handling of the patient that collected from the citizen / big data) to prevent and give better handling with a similar disease situation?

3. Can the Management Information System help doctors to do telemedicine in the future in Indonesia?

4. How ICT can be impactful to be used in Indonesia to support the medical sector?

\section{Literature Study \\ Covid-19}

Coronavirus is a positive single-strand RNA virus that belongs to the Orthocoronavirinae subfamily and has a crown-like spike on the surfaces. Covid-19 itself is caused by a 2019-nCoV infection that successfully notifiable in Taiwan on January 15, 2019. nCoV has similar characteristics with other viruses like SARS-CoV and MERS-Cov though when they have a different biologic characteristic and virulence when it comes to causes a spreading to the human body. It is believed that the 2019-nCoV was zoonotic (means it is spread by the animals, in this case, a bat). However, until the date, the origin or natural host for the 2019-nCoV is not clear.

\section{Covid-19 Spread}

In late December 2019, an outbreak of mysterious pneumonia characterized by fever, dry cough, and fatigue, and occasional gastrointestinal symptoms happened in a seafood wholesale wet market, the Huanan Seafood Wholesale Market, in Wuhan, Hubei, China.1 The initial outbreak was reported in the market in December 2019 and involved about 66\% of the staff there. The market was shut down on January 1, 2020, after the announcement of an epidemiologic alert by the local health authority on December 31, 2019. However, in the following month (January) thousands of people in China, including many provinces (such as Hubei, Zhejiang, Guangdong, Henan, Hunan, etc.) and cities (Beijing and Shanghai) were attacked by the rampant spreading of the disease.2 Furthermore, the disease traveled to other countries, such as Thailand, Japan, the Republic of Korea, Viet Nam, Germany, the United States, and Singapore. The first case reported in our country was on January 21, 2019. As of February 6, 2020, a total of 28,276 confirmed cases with 565 deaths globally were documented by WHO, involving at least 25 countries. The pathogen of the outbreak was later 
INTERNATIONAL JOURNAL OF ACADEMIC RESEARCH IN ACCOUNTING, FINANCE AND

MANAGEMENT SCIENCES

Vol. 11, No. 2, 2021, E-ISSN: 2225-8329 @ 2021 HRMARS

identified as a novel beta-coronavirus, named 2019 novel coronavirus (2019-nCoV), and recalled to our mind the terrible memory of the severe acute respiratory syndrome (SARS-2003, caused by another beta-coronavirus) that occurred 17 years ago (WHO, 2020).

\section{Covid-19 Classification in Indonesia}

The Covid-19 task force in Indonesia also gives a classification for people who have a chance to get infected by the virus, such as:

1. Orang Tanpa Gejala / Person Without Symptom (OTG)

- A person who doesn't have any symptom and have a chance to get infected by the COVID19 positive patient

- Unsymptom person who has direct and close contact with the COVID-19 positive patient

2. Orang Dalam Pemantauan / Monitored Person (ODP)

- Patient with fever (>=38 Celcius) or had a fever history or had a cough/flu/sore throat and traveled to infected area/country for the last 14 days

- Patient with mild flu or mild sore throat and had direct and closed contact to the COVID19 positive patient for the last 14 days

3. Pasien Dalam Pengawasan / Supervised Patient (PDP)

- Patient with Acute Respiratory Infections condition which has a fever (>=38 Celcius) or has a fever history with sore throat/cough/flu/mild pneumonia and traveled to infected area/country for the last 14 days

- Patient with Acute Respiratory Infections condition which has a fever (>=38 Celcius) or has a fever history with sore throat/cough/flu/mild pneumonia and had direct and closed contact to the COVID-19 positive patient for the last 14 days

- Patient with Acute Respiratory Infections condition which needs hospital treatment in hospital and there is no clinical reason that ensures the cause

\section{Methodology}

\section{Methodology Stages and Descriptive}

The descriptive method is one of a research method that is used to describe the problems that occur on the date and still going on, it specifically aims to describe what and what it is supposed to do when the topic of the research is happening. Characteristics of the descriptive method such as:

1. Concentrate on the solution which available in the date or in the actual problems that occurred

2. The data that been collected, explained and then analyzed, so this method also called an analysis method

I chose this method because of several reasons as follow:

1. This method makes it possible to give a glimpse of what should we do to face and solve the problems. Also can give a good solution to prevent it can happen again in the future

2. The research also can improve another topic to have a good environment and operational.

Methodology stages that used in this paper also can be described on the diagram below: 


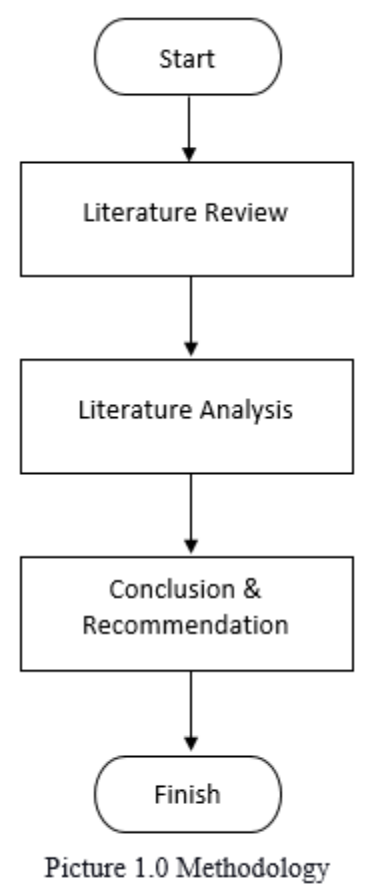

\section{Data Collection and Analysis Data Collection}

In this section, studies of previous studies related to this research are conducted and served as a guidline for conducting research, which later will be analyzed, and get the result of whether the result can be implemented in Indonesia as the solution and what is the solution that suit for Indonesia need. In this document, I do the data collection from the journal that been published before with the study case/issue related to different countries. In this paper, I search the specific published journal that discuss the specific themes that hopefully will support my paper. The three themes are:

1. The use of Health Management Information System (HMIS) to support patient with chronic disease.

2. The use of Information Technology (IT) in medical sector

3. The government action in crisis situations

With the conclusion of this paper, hopefully solution can be gained and earned and can be implemented by the Indonesian Government and the institutions when it comes to handle and support the patients with chronic disease. As well as give the example on how the IT can change the old perception and make the procedure in medical sector to be improved. Furthermore, this paper can bring new insight for the development of IT infrastructure in Indonesia to handle the country when it comes to a crisis condition like in this pandemic situation.

\section{Data Analysis}

Based on the study literature that I use to support this paper, there is some similarity based on how the technology that used or the solution used to solve the problems in the related sector and countries. I specifically choose the paper that discusses the chronic disease/illness since the Covid-19 itself might be resulting in some effects that worsen the condition of the patient. Some patients that 
INTERNATIONAL JOURNAL OF ACADEMIC RESEARCH IN ACCOUNTING, FINANCE AND MANAGEMENT SCIENCES

Vol. 11, No. 2, 2021, E-ISSN: 2225-8329 ๑ 2021 HRMARS

got diabetes/cancer / other chronic illness condition and infected by the COVID-19 virus, potentially worsen the health condition of themselves. The government of Indonesia said that there is still no case for a patient that died "pure" because of COVID-19, the patient that died potentially got a complication with their chronic disease (Bernardi, Sarker, \& Sahay, 2019). With this condition and situation, I choose the paper for my literature study that discusses the handle of chronic disease/illness. It is really important for the paper objectives that giving a conclusion or recommendation on how the Indonesian government can implement the techniques that proven successful or resulting in a positive sight before handling the patient with a chronic disease condition. Also, it is an urgent priority to have a good Health Information System that can be used widely by the citizen to have information about their health condition (Rizqo, 2020).

With Indonesia's geography that has many islands, it is difficult to spread the information especially the newest information that consumed whether for the staff in institutions or the public. Especially in the Covid-19 situation, one hoax news can be spread and no one is going to know whether it is true or not. Many of the news that showed how to make from hand sanitizer and mask on the internet that spread all over the social media. Sometimes, the tips can be harmful. Many professional doctors and the government staff that later clarify the hoax information (Prawira 2020). For the staff especially in the hospital, the wrong data can make a catastrophe condition. The wrong procedure to input the patient records in one Hospital located in one of the rural islands in Indonesia might be affecting the mismatched data in the Health Task Force for instance. This error later can affect the health procedure in that hospital, if the patient is infected, then no data can predict how many people that have touched directly to the patient. It will be increasing in positive cases that have been happening in Indonesia right now.

The infected patient has to handle with a proper procedure so they can not infect the health people, including the staff of the hospital. Many cases in Indonesia that the medical staff infected by the virus because the patients are lying and don't know that the symptom that they had is shown that they are infected. Later, many medical staff in a hospital in Indonesia dead because there is some lack of information regarding the infected patient (Salman, 2020). For handling the patient, it is proven that the use of an IT-based Health Information System in the medical sector can result in a positive effect, especially with the patient that got a chronic disease/illness. The detail of the effect as follows:

1. An accessible Health Information System (HIS) is crucial for the patient. Also, the HIS can impact patients like the inhaler usage behavior on asthma patients (Son, Brennan, \& Zhou, 2020).

2. The patients that use the IT-based system, can get a better health outcome than resulting the fewer emergency visits (Bao et al., 2020)

3. The framework which becomes a system used by the asthma patient is proven to identify the risk factor timely of the disease, also understanding what causing the asthma symptom. Moreover, the use of novel data sources like social media, patient's behavior becomes an alternative way to do the data collection for the system so both the patient and the medical staff can predict, prevent, handle and cure the asthma symptom (Zhang \& Ram, 2020)

4. There is a pressing need for more self-management (SM) interventions that place greater emphasis on collaborative relationships with patients and on supporting patients' efforts toward becoming active and engaged in managing their illness and its consequences (Savoli, Barki, \& Pare, 2020) 
INTERNATIONAL JOURNAL OF ACADEMIC RESEARCH IN ACCOUNTING, FINANCE AND MANAGEMENT SCIENCES

Vol. 11, No. 2, 2021, E-ISSN: 2225-8329 @ 2021 HRMARS

5. The patient adaptation from the chronic disease increased as a result of personal feedback such as a sense of the case, the cognitive need of the individual, and improvement of their health condition. Also, the use of a telemonitoring program can reduce medical alerts and improve patient adaptation. The telemonitoring system also becomes an efficient and effective choice for the patient to better self-manage their care/health condition (Brohman, Addas, Dixon, \& Pinsonneault, 2020)

6. The studies suggest that Information Technology-Based Self-Monitoring (ITSM) characteristics generally improve physical activity. Mobile applications and wearables (including pedometers and accelerometers) are the most frequently studied ITSM devices to track steps and physical activity time. It also has some positive impacts on dietary outcomes of the patient. Moreover, patients can have a better comprehension of their health problems, identify the trends and patterns of their result of a chronic condition. The ITSM also allows patients to enhance the understanding of their chronic disease condition's result to keep maintained (Jiang \& Cameron, 2020)

7. There is a critical need for connecting multiple HIS and data, including physiological signals, genomic biomarkers, EHR, and others to evaluate and support the health infrastructure for patients with chronic disease. Moreover, integrating the nontraditional data with traditional data sources to help the health staff more predictable for diagnose the patient. The staff can use traditional data and the data given by devices like IoT devices. Also, the Artificial Intelligence term can be used for disease prevention, detection, diagnoses, and treatment for the patient (Bardhan, Chen Hsinchun, \& Karahanna, 2020)

8. Self-Managed Healthcare Information System (HIS) is important to maintain the conditions of patients with chronic disease. The capacity to adapt to different diseases also becomes a need for patients with different diseases, symptoms, etc. The Health Care Information Systems needs to connect and integrate with connected stakeholders and government institutions to increase efficiency. Moreover, the use of HIS might support Hospitals located in rural areas (the doctor can communicate with another doctor if they have a problem in the hospital, it might it can upgrade the quality of the medication in the hospital. Also, HIS can improving patient's health outcomes after the patient is well. The chronic patient might be prolonging their life through secondary prevention and enhancing their quality of life (Ho, Guo, \& Vogel, 2019)

It is proven that the use of Health Information System can result in a good effect for the infected patient, even though there is some difference about the procedure and handling each serious/chronic disease, but still it can enhance the patient and improve the quality for handling, preventing and curing the patient. However, it still can be done if the quality of the infrastructure is not good enough to support the system. With the geography condition in Indonesia, it is hard to maintain the quality of each island in the technology sector or the medical sector. The Indonesian Government must find an effective way to solve the problem. I also found several papers that discuss how the government handled a similar condition and successfully reduce the impact of the disease condition. The explanation as follows:

1. Policymakers and Health Management Information System (HMIS) designers are faced with the challenge of meeting diverse user information needs across different levels of the healthcare system (e.g., from hospital managers to policymakers). It is important to make a 
flexible technology to balance the need for data integration while ensuring the coexistence of systems with incompatible goals and constraints in the country. Moreover, all stakeholders in the healthcare sector need to recognize the vital role of HMIS in delivering good healthcare. It will need professional doctors and healthcare managers to plan and design the HMIS so it can be used effectively and efficiently for the patient, the government, and the medical staff (Bernardi, Sarker, \& Sahay, 2019)

2. Many government staff was using IT applications to trace the movement of SARS patient, their contact, and the health of relevant staff and in-patients. Also, they were using email systems to spread and exchange the data from one institution to another institution. Later, the government took an active role in proposing and developing an information system to manage the data exchange across agencies and keep update the data through the agencies/institutions. Moreover, The Singapore experience suggests that organizations need to think ahead about how they can adapt their existing IT resources and capabilities in times of crisis. The IT infrastructure, technology resources, human IT talent, and collaboration capabilities are assets that will benefit crisis management activities (Pan, Pan, \& Devadoss, 2005)

3. The integration of IT infrastructure and the development of analytic capabilities involve significant and sustained commitment. To achieve improvements in healthcare quality and cost outcomes, practitioners must commit resources to build and facilitate IT and analytics infrastructure. Building the IT infrastructure involves gaining the consent of data owners, establishing protocols to accurately identify patients, interventions, costs, and outcomes, and then capturing and storing data in a secure environment. Providers and patients must be willing to share health data and must have the ability to choose how much data and with whom they would like to share. Furthermore, IT infrastructure and analytics can displace the procedures with the high cost and widen the chronic disease health status measures improve (Thompson et al., 2020)

\section{Conclusion and Recommendations \\ Conclusion}

Some conclusions obtained from this paper, such as:

1. Health Management Information System (HMIS) becomes a critical need in the medical sector. The patient can get detailed information about their condition, how the prevention, how to reduce the effect, and how to handle the condition, especially the patient with chronic illness.

2. The use of IT can be future opportunities to be used in the medical sector. It will help both the medical staff and the patient to maintain the health condition of the patient. From loT devices until the Artificial Intelligence (AI) is proven to improve the quality of the medical procedure for the patients.

3. Governments have to prepare a good health system by providing a good IT infrastructure in their country. The system must be efficient and effective to be used to maintain the condition of the patient, also good enough to be understood by the patient. Many patients don't have good technical knowledge about using technological devices. The government must ensure the system can be used practically by the patient and the medical staff. Furthermore, the use of IT in the medical system can reduce the cost for the governments to handle the patient in 
INTERNATIONAL JOURNAL OF ACADEMIC RESEARCH IN ACCOUNTING, FINANCE AND

MANAGEMENT SCIENCES

Vol. 11, No. 2, 2021, E-ISSN: 2225-8329 ๔ 2021 HRMARS

their country. Also, the governments need to adapt their IT resources and capabilities so the IT assets can be used in the crisis condition and making a responsive communication with other stakeholders as well as the public.

\section{Recommendations}

The author has some recommendations for the Government Indonesia to reduce the impact that resulted by the COVID-19 pandemic, such as:

1. With the geography situation in Indonesia, The Indonesian Government must develop and make an integrated Health Information System that will help each hospital and the medical institution to get updated data regarding patient records, patient history, and others. It is necessary to keep the data is gathered and informed through the medical institution in this Covid-19 situation to maintain and reduce the spread of the infection. Furthermore, it will benefit the government and the citizen of Indonesia to get true information regarding the Covid-19.

2. The government must ensure the IT and health infrastructure to support the system used for the mass needs of the citizen. IT resources and capabilities can help the country to handle the pandemic or other critical conditions.

3. The spreading information about the prevention, handling, curing of the disease also has to keep-maintained by the government and the medical staff. Also, the stakeholders have to collaborate with the government to make the agreement and regulation regarding the spreading of information about the Covid-19 or other serious disease

\section{References}

Antara. (2020). Referral Hospitals Prioritized for Covid-19 Patients with Severe Symptoms. Retrieved from https://www.medcom.id/english/national/4KZRzzpK-referral-hospitals-prioritized-forcovid-19-patients-with-severe-symptoms

ASEAN. (2018). Indonesians - Where do they live. Retrieved from https://asiancenturyinstitute.com/development/1467-indonesians-where-do-they-live

Bao, C., Bardhan, I. R., Singh, H., Meyer, B. A., \& Kirksey, K. (2020). Patient-Provider Engagement and Its Impact on Health Outcomes: A Longitudinal Study of Patient Portal Use.

Bardhan, I., Hsinchun, C., \& Karahanna, E. (2020). Connecting Systems, Data, and People: A Multidisciplinary Research Roadmap for Chronic Disease Management.

Beritasatu. (2020). Indonesia Confirms First Coronavirus Cases in Its Territory. Retrieved from https://jakartaglobe.id/news/indonesia-confirms-first-coronavirus-cases-in-its-territory/

Bernardi, R., Sarker, S., \& Sahay, S. (2019). The Role of Affordances in the Deinstitutionalization of a Dysfunctional Health Management Information System in Kenya: An Identity Work Perspective.

Brohman, K., Addas, S., Dixon, J., \& Pinsonneault, A. (2020). Cascading Feedback: A Longitudinal Study of a Feedback Ecosystem for Telemonitoring Patients with Chronic Disease.

Eloksari, E. A. (2020). 'It's punishable': Government finds 148 hoaxes related to COVID-19 spread. Retrieved from https://www.thejakartapost.com/news/2020/03/03/its-punishablegovernment-finds-148-hoaxes-related-to-covid-19-spread.html

Force, Task Covid-19. (2020). Pedoman Penanganan Cepat Medis dan Kesehatan Masyarakat COVID19 di Indonesia. Retrieved from https://covid19.go.id/p/protokol/pedoman-penanganan-cepatmedis-dan-kesehatan-masyarakat-covid-19-di-indonesia 
INTERNATIONAL JOURNAL OF ACADEMIC RESEARCH IN ACCOUNTING, FINANCE AND

MANAGEMENT SCIENCES

Vol. 11, No. 2, 2021, E-ISSN: 2225-8329 @ 2021 HRMARS

Ho, S. Y., Guo, X., \& Vogel, D. (2019). Opportunities and Challenges in Healthcare Information Systems Research: Caring for Patients with Chronic Conditions

Indonesia, Wonderful. (2020). Large Scale Social Restriction Implementation. Retrieved from https://www.indonesia.travel/gb/en/news/large-scale-social-restriction-implementation

Jiang, J., \& Cameron, A. F. (2020). IT-Enabled Self-Monitoring for Chronic Disease Self-Management: An Interdisciplinary Review.

Loasana, N. (2020). Indonesia now leads Southeast Asia in confirmed coronavirus cases. Retrieved from https://www.thejakartapost.com/seasia/2020/04/17/indonesia-now-leads-southeast-asiain-confirmed-coronavirus-cases.html

Loasana, N. A. (2020). Most Indonesians concerned about overcapacity at health facilities during pandemic: Survey. https://www.thejakartapost.com/news/2020/05/05/most-indonesiansconcerned-about-overcapacity-at-health-facilities-during-pandemic-survey.html

Muthiariny, D. E. (2020). Jakarta Records Over 2,000 New Silent COVID-19 Carriers in a Day. Retrieved from https://en.tempo.co/read/1343669/jakarta-records-over-2000-new-silent-covid-19carriers-in-a-day

Pan, S. L., Pan, G., \& Devadoss, P. R. (2005). E-Government Capabilities and Crisis Management: Lessons From Combating SARS in Singapore.

Prawira, A. E. (2020). Dokter Ungkap Bahaya Bikin Hand Sanitizer Sendiri, Salah-Salah Bisa Meledak. Retrieved from https://www.liputan6.com/health/read/4208813/dokter-ungkap-bahaya-bikinhand-sanitizer-sendiri-salah-salah-bisa-meledak

Rizqo, K. A. (2020). Pemerintah: Tak Pernah Ada Pasien Meninggal karena Corona, Selalu Komplikasi. Retrieved from https://news.detik.com/berita/d-4934352/pemerintah-tak-pernah-ada-pasienmeninggal-karena-corona-selalu-komplikasi

Salman, G. (2020). IDI Ungkap Penyebab Banyak Tenaga Medis di Jatim Meninggal karena Covid-19. Retrieved from https://surabaya.kompas.com/read/2020/07/02/14483101/idi-ungkappenyebab-banyak-tenaga-medis-di-jatim-meninggal-karena-covid-19?page=all

Saubani, A. (2020). Jubir Covid-19 Akui Sempat Ada Kesalahan Data Pasien Positif. Retrieved from https://republika.co.id/berita/q7qyk7409/jubir-covid19-akui-sempat-ada-kesalahan-datapasien-positif

Savoli, A., Barki, H., \& Pare, G. (2020). Examining How Chronically III Patients' Reactions to and Effective Use of Information Technology Can Influence How Well They Self-Manage Their Illness.

Sheany. (2020). The Great Disconnect: poor early response against COVID-19 puts Indonesia on worrisome trajectory. Retrieved from https://medium.com/@sheanyyas/the-great-disconnectpoor-early-response-in-indonesia-sets-us-on-a-worrisome-trajectory-c26f15254539

Son, J., Brennan, P. F., \& Zhou, S. (2020). A Data Analytics Framework For Smart Asthma Management Based on Remote Health Information Systems with Bluetooth-Enabled Personal Inhalers.

Suprapto, Y. (2020). As Indonesia fights COVID-19, warmer termperatures drive up dengue cases. Retrieved from https://news.mongabay.com/2020/04/as-indonesia-fights-covid-19-warmertemperatures-drive-up-dengue-cases/

Syakriah, A. (2020). COVID-19: Java on 'red alert' as deaths spike. Retrieved from https://www.thejakartapost.com/news/2020/05/14/covid-19-java-on-red-alert-as-deathsspike.html

Thompson, S., Whitaker, J., Kohli, R., \& Jones, C. (2020). Chronic Disease Management: How IT and Analytics Create Healthcare Value Through the Temporal Displacement of Care. 
INTERNATIONAL JOURNAL OF ACADEMIC RESEARCH IN ACCOUNTING, FINANCE AND MANAGEMENT SCIENCES

Vol. 11, No. 2, 2021, E-ISSN: $2225-8329$ @ 2021 HRMARS

WHO. Coronavirus disease. (COVID-19) pandemic. Retrieved on June 13, 2020 from https://www.who.int/emergencies/diseases/novel-coronavirus-2019

Zhang, W., \& Ram, S. (2020). A Comprehensive Analysis of Triggers and Risk Factors for Asthma Based on Machine Learning and Large Heterogeneous Data Sources. 